\title{
DE NOVO PSYCHOGENIC SEIZURES AFTER EPILEPSY SURGERY
}

\author{
CASE REPORT
}

\author{
MARIA AUGUSTA MONTENEGRO, MARILISA M. GUERREIRO, ANNA ELISA SCOTONI, \\ FLORINDO STELLA, ANDREA A.A. LEONE, DONIZETE C. HONORATO, BENITO P. DAMASCENO, \\ CARLOS A. M. GUERREIRO, FERNANDO CENDES
}

\begin{abstract}
The occurrence of de novo psychogenic seizures after epilepsy surgery is rare, and is estimated in $1.8 \%$ to $3.6 \%$ Seizures after epilepsy surgery should be carefully evaluated, and de novo psychogenic seizures should be considered especially when there is a change in the ictal semiology. We report a patient with de novo psychogenic seizures after anterior temporal lobe removal for refractory temporal lobe epilepsy. Once psychogenic seizures were diagnosed and psychiatric treatment was started, seizures stopped.
\end{abstract}

KEY WORDS: psychogenic seizure, epilepsy surgery.

\section{Crises psicogênicas de novo após cirurgia de epilepsia: relato de caso}

RESUMO - A ocorrência de crises psicogênicas de novo após cirurgia de epilepsia é rara, e é estimada em 1,8\% a 3,6\%. Crises após cirurgia de epilepsia devem ser cuidadosamente avaliadas, e crises psicogênicas de novo devem ser consideradas especialmente quando houver uma mudança na semiologia ictal. Relatamos o caso de uma paciente com crises psicogênicas de novo após lobectomia temporal anterior realizada para tratamento de epilepsia temporal de difícil controle. Uma vez feito o diagnóstico de crise psicogênica e iniciado tratamento psiquiátrico, as crises foram controladas.

PALAVRAS-CHAVE: crise psicogênica, cirurgia de epilepsia.

Seizure recurrence following surgical treatment of refractory epilepsy is usually characterized by events which are similar to the preoperative ones, and may indicate a poor prognosis. Acute postoperative generalized tonic-clonic or focal motor seizures associated with a precipitating factor such as subtherapeutic antiepileptic drug (AED) blood levels, meningitis or metabolic disturbances often have a good prognosis ${ }^{1}$.

Except for changes in duration of ictal and post-ictal symptomatology, seizures clinically different from those recorded before surgery are rare, and may represent psychogenic seizures ${ }^{2}$.

We report a patient with de novo psychogenic seizures after anterior temporal lobe removal for refractory temporal lobe epilepsy.

\section{CASE}

An 18 year-old right handed girl experienced her first seizure at age 11. During the following years seizures increasingly became more frequent, and by the time she was 17 years-old she had four or five complex partial seizures every 10 to 15 days. Seizures were characterized by staring,

Departamento de Neurologia - Universidade de Campinas (FCM / UNICAMP). Aceite: 25-março-2000. 
eye blinking and bilateral automatic arms movements. AEDs used included phenobarbital, carbamazepine, valproic acid, clobazam and phenytoin. Each medication was introduced in monotherapy arriving to the maximum tolerated dose. Whenever monotherapy failed, various combinations were tried. EEGs revealed generalized, irregular, spike-wave complexes and sharp waves over the right fronto-temporal region. Video EEG monitoring showed three seizures beginning at the right temporal region, clinically similar to the ones described above. MRI showed right hippocampal atrophy. Ictal and interictal single photon emission computed tomography (SPECT) revealed hyper and hypoperfusion in the right temporal lobe, respectively. Neuropsychological assessment showed estimated IQ (WAIS-R) of 83 and left hemisphere speech dominance (Dichotic Listening Test). Her performance in attentional Vigilance Test-Strub \& Black, Trail Making Test and Wisconsin Card Sorting Test was normal. The Wechsler Memory Scale-Rer (WMS-R) showed normal global memory and verbal memory, and a deficit in visual memory and delayed recall. Recall of 10 words associated to figures (test of logical memory) was 50\% defective. Developmental milestones were normal and she had no history of previous febrile seizures. Neurological examination was unremarkable.

A right anterior temporal resection, including amygdala and the anterior portion of the hippocampus, was performed. Two weeks after the surgery she complained of headache, fever, myoclonic jerks involving the whole body and auras characterized by fear or sensation of "chewing sand", which she had never had before. Brain computerized tomography and cerebrospinal fluid examination were performed to rule out bleeding or infection. Valproic acid was then added to phenytoin and clobazam, which was her regimen previous to surgery.

She kept coming to the emergency room of our University Hospital every week, still claiming of headache, fever and daily seizures, now characterized by head turning to the left followed by a tonic seizure, which had started 4 weeks after the surgery. Clinical and neurological examination were normal. Seven months after the surgery she was again admitted to the hospital to undergo video EEG telemetry which was performed for 30 days without a single seizure being recorded. The patient claimed of having some auras, but never pressed the push-bottom. Psychiatric evaluation diagnosed depression according to the DSM-IV ${ }^{3}$ criteria, most likely starting before the surgery. She was started on psychoteraphy and nortriptyline was introduced and she has been seizure free since then. Follow-up period was 11 months after this treatment.

\section{DISCUSSION}

The occurrence of de novo psychogenic seizures after epilepsy surgery is rare, and is estimated in $1.8 \%$ to $3.6 \%{ }^{2,4}$. There are a few reports about its occurrence, with a total of 8 cases described in the literature ${ }^{2,4-6}$. Parra et al. ${ }^{2}$ reported the first 3 cases documented with video EEG telemetry, and reinforced its importance in the diagnosis of psychogenic seizures. Unfortunately, we could not document the seizures with video EEG telemetry, despite 30 days of continuous monitoring.

Although the patient complained of auras two weeks after the surgery, they were different from those before surgery, and it is not clear if they represent true seizures or were also non-epileptic. The myoclonic jerks (which might be associated with the generalized epileptiform activity present in several EEGs) were neither witnessed by a physician nor recorded, and could represent a second epileptic syndrome, although this is unlikely.

Onset of psychogenic seizures vary in literature, and has been reported since the immediate postoperative period to 78 months after surgery. Seizure frequency has been reported to be high, and it is consistent with the pattern presented by our patient ${ }^{2,4}$.

Depression is a known risk factor for developing psychogenic seizures ${ }^{5}$. Once psychogenic seizures were diagnosed and psychiatric treatment was started, seizures stopped. The good outcome of psychogenic seizures in this case is in keeping with Kanner et al. ${ }^{7}$ report in which the authors concluded that the absence of personality disorder and/or physical and emotional abuse may contribute 
to a better prognosis. Parra et al. ${ }^{2}$ also reported a good acceptance of the diagnosis (two patients remained seizure free and one had more than $75 \%$ of improvement).

We conclude that the occurrence of seizures after epilepsy surgery should be carefully evaluated. When there is a change in the ictal semiology, de novo psychogenic seizures should be considered.

\section{REFERENCES}

1. Malla BR, O’Brien TJ, Cascino GD, et al. Acute postoperative seizures following anterior temporal lobectomy for intractable partial epilepsy. J Neurosurg 1998;89:177-182

2. Parra J, Iriarte J, Kanner AM, Bergen DC. De novo psychogenic nonepileptic seizures after epilepsy surgery. Epilepsia 1998;39:474-477.

3. American Psychiatric Association. Diagnostic and statistical manual of mental disorders. 4.Ed. Washington, D.C.: American Psychiatric Association, 1994.

4. Ney GC, Barr WB, Napolitano C, Decker R, Schaul N. New-onset of psychogenic seizures after surgery for epilepsy. Arch Neurol 1998;55:726-730.

5. Krahn LE, Rummans TA, Sharborough FW, Jowsey SG, Cascino GD. Pseudoseizures after epilepsy surgery. Psychosomatics 1995;36:487-493.

6. Ferguson SM, Rayport M. The adjustment to living without epilepsy. J Nerv Ment Dis 1965;140:26-37.

7. Kanner AM, Pierre-Louis S, Frey M. Relationship between psychiatric history and outcome of psycogenic pseudoseizures. Neurology 1996;46(Suppl 2):304. 